\title{
Social Functions of the Kamang Mudiak Folklore Text: as Inauguration of Local Cultural Heritage Hidayati Azkiyaa1 ${ }^{\text {1* }}$, Romi Isnandab2, Syofianic3
}

Prodi Pendidikan Guru Sekolah Dasar, Fakultas Keguruan dan Ilmu Pendidikan, Universitas Bung Hatta ${ }^{a}$ Prodi Pendidikan Bahasa Indonesia, Fakultas Keguruan dan Ilmu Pendidikan, Universitas Bung Hatta ${ }^{\mathrm{b}, \mathrm{c}}$ $\underline{\text { hidayatiazkiya@,bunghatta.ac.id }}^{1 *}$; romiisnanda@,bunghatta.ac.id ; syofiani@,bunghatta.ac.id

*author correspondence

\begin{tabular}{ll}
\hline Informasi artikel & \\
\hline Sejarah artikel: & \\
Diterima: & I5 Juli 202I \\
Revisi & 27 Oktober 202I \\
Dipublikasikan & 30 Oktober 202I \\
\hline
\end{tabular}

ABSTRAK

Penelitian ini dilatarbelakangi oleh melemahnya khasanah budaya karena perkembangan zaman dan teknologi serta modernisasi. Kebudayaan yang ada di daerah Kamang Mudiak salah satunya dalam bentuk sastra lisan tidak dikenal dan

Kata kunci: diketahui lagi oleh generasi muda. Padahal mengenal budaya dan melestarikannya merupakan bagian dalam mengukuhkan budaya lokal sehingga tidah hilang seiring

Fungsi Sosial

Cerita Rakyat

Budaya Lokal perkembangan zamn. Oleh karena itu, penelitian ini difokuskan pada fungsi sosial cerita rakyat kamang mudiak: pengukuh warisan budaya lokal. Hal ini bertujuan mendeskripsikan fungsi sosial teks sastra lisan cerita rakyat Kanagarian Kamang Mudiak. Metode penelitian yang digunakan adalah metode deskriptif kualitatif. Data penelitian ini adalah teks cerita rakyat di Kanagarian Kamang Mudiak. Pengumpulan data dilakukan melalui perekaman, pencatatan, pengamatan, dan wawancara. Sedangkan untuk menguji keabsahan data, penelitian ini menggunakan teknik triangulasi. Hasil Penelitian menunjukkan bahwa terdapat fungsi sosial dalam teks cerita rakyat Kamang Mudiak yaitu: (a) mengembangkan integrasi Masyarakat yang terdapat dalam teks cerita Ngalau Kalam Tabik, Makam Panjang, Salodang, Tuanku Nan Renceh/ Harimau Nan Salapan, Ngalau Tarang Batu Biaro Bansa. (b) Alat Kontrol Sosial yang terdapat dalam teks cerita Salodang, Tuanku Nan Renceh/ Harimau Nan Salapan, Ngalau Tarang Batu Biaro Bansa. (c) Pengukuhan solidaritas sosial yang terdapat dalam teks cerita Danau Tarusan, Salodang, dan Tuanku Nan Renceh/Harimau Nan Salapan. (d) Identitas kelompok yang terdapat dalam teks cerita Danau Tarusan, Lasuang 3 Indu, Makam Panjang, Salodang, Tuanku Nan Renceh/Harimau Nan Salapan, Ngalau Tarang Batu Biaro Bansa. (e) Harmonisasi komunal yang terdapat dalam teks cerita Asal Mula 5 Sungai, Ngalau Kalam Tabik, Asal Mulo Kamang Mudiak dan Hilia, Lasuang 3 Indu, Makam Panjang, Salodang, Tuanku Nan Renceh/Harimau Nan Salapan. Maka dapat disimpulkan bahwa kehadiran cerita rakyat dalam masyarakat dapat menjalankan aktivitas kehidupan antara yang satu dengan yang lainnya, karena di dalamnya terkandung fungsi sosial bagi masyarakat di sekitar dan menjadi penciri untuk daerah masing-masing dalam mengukuhkan budaya lokal.

Key word:

Social Function

Folklore

Local Culture

\begin{abstract}
This research is motivated by the weakening of cultural treasures due to the development of the times and technology and modernization. The culture in the Kamang Mudiak area, one of which is in the form of oral literature, is unknown and known to the younger generation. Whereas knowing culture and preserving it is part of strengthening local culture so that it does not disappear with the development of time. Therefore, this study focuses on the social function of the kamang mudiak folklore: strengthening local cultural heritage. It aims to describe the social function of the oral literary text of the Kanagarian folklore Kamang Mudiak. The research method used is descriptive qualitative method. The data of this research are folklore texts in Kanagarian Kamang Mudiak. Data was collected through recording, recording, observing, and interviewing. Meanwhile, to test the validity of the data, this study used triangulation techniques. The results of the study indicate that there are social functions in the Kamang Mudiak folklore text, namely: (a) developing community integration contained in the story text Ngalau Kalam Tabik, Makam Panjang, Salodang, Tuanku Nan Renceh/Harimau Nan Salapan, Ngalau Tarang Batu Biaro Bansa. (b) (b) Social Control Tools contained in the story text Salodang, Tuanku Nan Renceh/Harimau Nan Salapan, Ngalau Tarang Batu Biaro Bansa. (c) Strengthening social solidarity contained in the story
\end{abstract}


text Danau Tarusan, Salodang, dan Tuanku Nan Renceh/Harimau Nan Salapan. (d) The identity of the group contained in the story text Danau Tarusan, Lasuang 3 Indu, Makam Panjang, Salodang, Tuanku Nan Renceh/Harimau Nan Salapan, Ngalau Tarang Batu Biaro Bansa. (e) Communal harmonization contained in the story text Asal Mula 5 Sungai, Ngalau Kalam Tabik, Asal Mulo Kamang Mudiak dan Hilia, Lasuang 3 Indu, Makam Panjang, Salodang, Tuanku Nan Renceh/ Harimau Nan Salapan. So it can be concluded that the presence of folklore in society can carry out life activities between one another, because it contains social functions for the surrounding community and becomes a marker for their respective regions in strengthening local culture.

Copyright (C) 2018 Universitas Ahmad Dahlan. All Right Reserved

\section{Introduction}

Culture is a complex whole which includes knowledge, belief, art, law, morals, habits, and skills acquired by humans as members of society. The cultural diversity that exists in an area is also called "multicultural" (Devianty, 2017: 24). One of the multicultural developments in society is in the form of oral literature. As part of culture, of course, oral literature expresses events that contain moral, religious values, customs, fantasies, proverbs, songs, folklore, and mantras. This is of course owned by each region, it's just that it is integrated in people's lives with different procedures and languages. The differences that exist in each region in Indonesia can be used as local wisdom (Ibrahim, 20I7: 7).

The local wisdom is contained in the traditions or habits of the people from generation to generation which are created based on the culture of the community. The existence of culture creates habits that cannot be denied in people's lives. The emergence of tradition cannot be predicted, but appears naturally based on the habits of the adherents or indigenous peoples. Hamidy (2006:57) explains that traditions arise based on indigenous peoples. Indigenous peoples are communities that are maintained and composed by customary values. These values are formed in a set of norms that frame the habits of a society in carrying out all behaviors. Furthermore, traditional society is a society that is full of community values which are manifested in the form of behavioral references. Based on this statement, it can be stated that tradition is a community habit that is carried out from generation to generation as a reference for cultural behavior patterns. One of them is oral literature.

Oral literature has roots that are closely related to the history of the Indonesian nation, both socio-cultural, moral, religious, to political aspects. Oral literature is included in the study of folklore which is inherited from generation to generation. One type of oral literature that exists in society is folklore. Folklore is part of oral literature which is spread orally from one person to another (Dewita, 2019:260). One area that has local wisdom in the form of folklore is the Kamang Mudiak area. Kamang Mudiak is one of the areas located in Kamang Magek District, Religious District, West Sumatra Province. The name of the Kamang Mudiak area comes from the word Kamanga waklai which comes from the Minangkabau language and means "why us again". This is of course born from stories that have their own local wisdom values in them (Isnanda, 2019:40).

At this time, the existence of folklore in the Kenagarian Kamang Mudiak community has begun to disappear. People only recognize physical evidence which is used as a place for mere tourist visits. This is because the younger generation seems to tend to think that local culture is no longer relevant to the life of today's society. Therefore, they often adopt culture from outside which is disseminated in various forms. One form of the younger generation's love for foreign cultures is to collect comics with Western cultural nuances. If they still remain silent and only keep trying to preserve the ancestral culture, they feel they belong to the group of people who are still primitive or lack knowledge of the times. If this is allowed, it is feared that the ancestral culture which is also part of local wisdom will become extinct.

The negative assumptions of the younger generation towards regional culture are not only at the level of concern about the loss of ancestral cultural heritage, but also relates to the personality of the younger generation which is dominated by foreign cultures. If the absorption of foreign culture is carried out by the younger generation without being accompanied by religious and cultural values, then this is one of the media that will destroy the personality of the younger generation, so that the character education launched by the government in the world of education is difficult to achieve.

Based on the description that has been put forward, research on folklore in Kenagarian Kamang Mudiak, Kamang Magek District, Agam Regency is important to do. In addition to making an inventory of the culture of the Kanagarian Kamang Mudiak community as a local cultural heritage confirmation, this research is also important in an effort to identify and classify the social functions that have been collected later. The theory used in analyzing social functions in folklore found in Kenagarian Kamang Mudiak Kec. Kamang Magek Kab. Religion is according to Hasanuddin WS (2003: I9I), that divides the social function of folklore into 5 parts, namely: (a) Developing 
Community Integration, namely through the formation of new myths with the style of rejecting old myths, people can act wisely. Through the formation of new myths, for example the myth that kings or leaders or community leaders have a tendency to make mistakes and mistakes. Therefore, the actions of leaders or community leaders must be controlled by the community. Thus, the leader avoids acting arbitrarily. (b) Social Control Tools, namely through new myths, the community gains another understanding of how to exercise social control over social systems and social systems. For example, through role models. Making a character to be imitated and idolized, should not be done with blind faith, because in fact no human being is perfect in his life. (c) Strengthening Social Solidarity, namely liberation myths can strengthen social solidarity. The myth that common people can be wiser than their leaders in living life's challenges, raises awareness that wisdom in dealing with life is not determined by social life, but by self-understanding. (d) Group Identity, namely through the myth that group identity can be further formed and strengthened. Group pride is needed to motivate life. Loss of motivation and the emergence of low self-esteem will kill creativity. Without creativity, the quality of life will decrease considerably. And (e) Communal Harmonization, namely the glory of a person or group of people is not determined by lineage, but by the quality of himself which, among other things, is formed through the education process, fostering communal harmonization. Thus, conflict and exclusion of people whose origins are not clear can be avoided.

Based on the explanation of the theory, the analysis carried out is expected to be one way to overcome the loss of national cultural assets. And can strengthen local cultural heritage from folklore texts in Kanagarian Kamang Mudiak.

\section{Method}

This research is a qualitative research with descriptive method (Moleong, 2010). Qualitative research is research that produces analytical procedures that do not use statistical analysis procedures or other quantification methods. The data of this study are oral literature data about multicultural education in the folklore of Kamang Mudiak, Kamang Magek District, Agam Regency, West Sumatra Province. Data collection was carried out in two stages. The first stage was the recording stage of the oral literature of the Kenagarian folklore Kamang Mudiak. Informants' utterances about oral literature on folklore were recorded using a recording device, such as (audio, audiovisual, video camera). The results of the recording of the oral literature of the Agam Regency folklore. The second stage is collecting data about the storytelling environment. Data about the storytelling environment were collected through recording, observation, and interview techniques. Meanwhile, to test the validity of the data, this study used triangulation techniques. The data that has been obtained will then be analyzed through the following stages. (I) Data inventory stage: Data is collected from informants through two stages, namely (a) recording, transcription, transliteration and (b) observation, recording, and interview stages; (2) Data classification/analysis stage: The data that has been obtained through the inventory stage is further classified/analyzed based on the established theory. (3) The stage of discussion and conclusion of the results of data classification/analysis. Furthermore, it is discussed whether the results of the classification/analysis of the data are in accordance with the theoretical framework or not. If it is not appropriate, is the discrepancy only on the difference in variants or variations or is it contrary to the existing theory.

\section{Results and Discussion}

The data of this study are oral literature data about social functions in the folklore of Kamang Mudiak, Kamang Magek District, Agam Regency, West Sumatra Province. The data obtained from the informant's speech about the oral literature of folklore recorded using a recording device, (HP). Data were obtained from 6 informants in Kamang Mudiak. The informants came from different villages such as: Pauah, Tabik, Parik Panjang, Bansa and Hilir all of which are in the same sub-district. Informants also have different work backgrounds and can be used as sources of data from folklore in their respective regions. Informants get the story by word of mouth by previous people or their families. All of the informants are also more than 60 years old and have become influential people in their respective villages. The 6 informants were met by the research team in their respective villages or homes to obtain information. The research team recorded stories told by informants about regional origins or myth in their respective villages. The data obtained from the informants were in the form of video recordings, then the recordings (spoken language) were transcribed into written language, then transliterated into Indonesian. Furthermore, the data is classified and analyzed according to theory. Data collection about the storytelling environment was collected through recording, observation, and interview techniques. The research team conducted interviews to determine the biodata of the informants and the level of knowledge of the informants about folklore as well as observations to see the locations told by the informants. All data about informants, transcription data, and transliteration are included in the documentation of research activities. The data obtained from the informants are that there are nine 
story texts about Asal Mula 5 Sungai, Ngalau Kalam Tabik, Asal Mulo Kamang Mudiak dan Hilia, Danau Tarusan, Lasuang 3 Indu, Makam Panjang, Salodang, Tuanku Nan Renceh/ Harimau Nan Salapan, and Ngalau Tarang Batu Biaro Bansa. In the following, some of the findings of this study will be described in detail.

\section{Folklore Social Functions}

\section{a. Developing Community Integrity}

Folklore packaged in the frame of local traditions of the local community can certainly function to develop community integrity. People can take knowledge of the events that appear in folklore and become the basis for thinking and behaving. Folklore can form a new understanding by rejecting the understanding in old folklore. With this new integrity or this new knowledge, the community's integrity towards an event can develop along with the existing level of understanding and knowledge. We can understand this, for example, kings or community leaders are not all wise. This view provides a new condition for the community that leaders or community leaders also have a tendency to make mistakes and mistakes. Based on the folklore of the Kamang Mudiak community that has been studied, it is found that the folklore of Tuanku Nan Renceh/Harimau Nan Salapan functions to develop community integrity. This folk tale tells how Tuanku Nan Renceh traveled in his struggle that he finally realized his mistakes and made a mistake in the war strategy. This story can be understood to serve to provide a new understanding that a Tuanku Nan Renceh also has mistakes and mistakes. However, the integrity given is honesty and good deeds will bring good things too. This is what makes Tuanku Nan Renceh admit his mistake and listen to his colleague's opinion. More clearly, consider the following quote.

Tuangku Nan Renceh melakukan kesalahan tentang strategi perang yang dilakukannya, dia tidak pernah segan untuk mengakuinya dan mendengarkan masukan dari semua aggotanya. Mereka disebut disebut dengan Harimau Nan Salapan.

Based on these data, it is known that not all community leaders can do the community or their subordinates wisely. For example, Tuanku Nan Renceh realized his mistake and promised not to repeat it.

\section{b. Establishing Social Control}

The folklore of Kamang Mudiak also serves as a means of social control. From folklore myths are formed based on requests for old myths. In this condition, the community gains another understanding of how to exercise social control over the social system and social system. Based on the results of the study of the folklore of Salodang. That Haji Salam who went to Mecca using Salodang through a stream of water from a 7 -storey sarasah. From the story, social control is obtained about people's beliefs about the journey that has been carried out by Haji Salam with Salodang. There an incident occurred that was beyond reason and made people confused. Therefore, the story is made that nothing is impossible if Allah has willed then all of that will happen even though it is beyond reason and logic. This can be seen from the following quote.

Kemungkinan di bawah Sarasah itulah Haji Salam yang pergi ke Mekah dengan Salodang. Salodang itu adalah upiah/pelepah pinang. Jadi air dari sarasah yang 7 tingkat itu ada aliran pembuangannya di situ, jadi dari aliran pembuangan itu Haji Salam pergi ke Mekah dengan menggunakan salodang melalui aluran air dari sarasah.

From the quote, that the social control that occurs in society is to believe in Haji Salim who made the trip to Mekah by using Salodang even though it doesn't make sense. Because the journey to Mecca is not as easy as one thinks. However, it can be accepted that the community believes in Haji Salim journey as a kyai and is religious and community leader.

Furthermore, the folklore of Lasuang 3 Indu which tells about 3 lasuang of mortar that cannot be separated from each other. If that is done, there will be disastrous and unreasonable things. This can be seen from the following quote.

Di tanah orang sikumbang, orang sikumbang itu adalah orang 3 indu (Ibu). Makanya nama lesung itu lesung 3 indu. Lesung itu sekarang berada di daerah Aia Tabik, asal muasalnya dulukan memang setiap tahunnya punya lesung, jadi yang dua ini serangkali terpisah. Dari legenda yang diterima itu pun memang yang kecil itu pernah dipindahkan, yang dipindahkan ini, mengakibatkan yang serangkali heboh, seperti orang yang sedang menumbuk siang dan malam, karena temannya yang hilang itu. Jadi orang-orang 
mengatakan itu adalah anaknya, si anak ini kembali dengan sendirinya, menemui orang tuanya, lalu berhenti pulalah suara menumbuk itu.

From the quote, that social control occurs in society regarding the relationship between mother and child as well as leaders and subordinates who must work hand in hand and together. If they do not help each other and have the same or separate ideas, there will be disaster and chaos in the family or society.

\section{c. Social Solidarity Affirmation}

The view which assumes that the common people can be wiser than their leaders leads to new understanding and can strengthen social solidarity. This can provide an understanding that in living the various challenges of life in society, social status does not affect a person to be wise and fair. This view raises awareness in the community that wisdom in dealing with life is not determined by social status, but by self-understanding. The folklore of the Kamang Mudiak community also serves to strengthen social solidarity. This can be seen in the folklore of Lake Tarusan. This folk tale tells of a man who is looking for water for his wife and for them to live a better life and not lack. So the man went down the hill and kept looking until he found a lake and it was called Lake Tarusan because he was looking for it constantly. Then bringing the water for his wife, it turns out that the wife has given birth and they come down from the hill and live on the shores of Lake Tarusan. This can be seen in the following quote.

Di atas bukit ada sepasang suami istri. Istrinya sedang hamil dan ternyata air susah di dapat di atas bukit. Karena sudah hamil besar air susah didapat sehingga suami turun ke bawah bukit mencari air. Laki-laki itu membawa parang (ladiang) untuk mencari jalan untuk menuruni bukit sehingga sampai ke bawah untuk mencari air. Sesampai di bawah maka dia mendapatkan air di danau yang terus menerus mencari maka diberilah nama Danau Tarusan. Lalu dia pergi ke atas bukit untuk menjemput istrinya yang sedang hamil besar dan ternyata istrinya sudah melahirkan. Maka, mereka turunlah ke bawah dan hidup di tepi danau serta tidak memiliki kekurangan lagi. Seperti yang mereka rasakan waktu tinggal di atas bukit.

The folklore of Lake Tarusan serves to strengthen social solidarity that life requires struggle, an earnest effort to obtain a decent life and is recognized by the community. Even if life is felt to be poor and deprived due to persistence, all of that will be overcome with sincerity and strong determination.

\section{d. Group Identity}

Folklore functions to form group identity. With the existence of folklore, it is possible to know the characteristics of certain people based on their way of thinking, lifestyle, and social conditions. Based on the research that has been done, the folklore of the Kamang Mudiak community serves to form the identity of the community. This can be seen in the folklore of the Harimau Nan Salapan in the folklore that illustrates how the people of Kamang Mudiak believe Tuanku Nan Renceh as the leader of the Harimau Nan Salapan in defending their country and society from invaders. Even though Tuanku Nan Renceh also has his shortcomings, this is not an obstacle to making him a brave leader who knows no fear or defeat. This can be seen from the quote from the story.

Harimau yang delapan adalah pejuang pada zaman perang paderi yaitu delapan orang tokoh paderi itu berasal dari Agam, lambang Agam itu harimau, maka dijadikanlah nama kelompok beliau Harimau Nan Salapan yang dipimpin oleh Tuanku Nan Renceh. Kenapa dinamapakan Tuanku Nan Renceh karena renceh itu artinya lincah, gesit, dan kecil. Itu menunjukkan cirinya, maka diberilah gelar Tuanku nan Renceh. Tungku Nan renceh merupakan pimpinan antara delapan pejuang tersebut. Saat Tuangku Nan

Renceh melakukan kesalahan tentang strategi perang yang dilakukannya, dia tidak pernah segan untuk mengakuinya dan mendengarkan masukan dari semua aggotanya.

Furthermore, the folklore of the Asal-Usul Limo Sungai which tells the story of five rivers and the characteristics of the people or people who live in the river. This shows the identity of a group in each region and shows the nature and character of the community according to the naming of the river. This right can be seen from the following quote.

Dahulu ada pauah besar. Maka dinamakanlah lurah pauah, lurah pauah ini terletak di asal mula Nagari Pauah dari mangga pauah, yang namanya kolam. Banyak namanya, ada orang yang mengatakan kolam besar. Di Pauah terdapat 5 sungai, yang pertama Sungai Kasiakan yang terletak di ujung Sitinjau Balau, lalu Sungai Sirah di Tabing, Sungai Dareh, Sungai Bawak, Sungai Sonsang di pintu barangay. Cerita 
penyebab 5 sungai ini, dahulu air mengalit di sungai tersebut, di sungai sonsang airnya banyak, kalau Sungai Sirah, pada waktu hujan lebat aimna merah, kalau di Sungai Kasiak, kata orang, dulu itu banyak jeruk/limau di sana, namanya jeruk /limau kasiakan, kalau Sungai Bawak, kata orang karena dulu banyak biawak di sana, biawak ini memakan itik/bebek, kalau Sungai Dareh ini, orang-orang di sana keras suaranya makanya namanya dareh, maksudnya saat dia berbicara dia berteriak-teriak, tidak pandai berbicara dengan pelan/lembut.

Based on the story that the origin of the name of the river is based on the character and identity of the people. This shows the identity of the existing group in the community from the naming of the river.

\section{e. Communal Harmonization}

Folklore can provide nuances of harmonization. An understanding that the glory of a person or group of people is not determined by lineage, but by the quality of himself which is formed through the educational process, fostering communal harmonization. This can be seen in the folklore of the Kamang Mudiak community with the title Makam Panjang. This can be seen from the connection of each grave so that it forms a unified whole in the relationship between families so that people think that each grave is located in each different area, if a straight line is taken it will be related. This can be seen from the following story.

Menggelegarnya kuburan-kuburan yang ada di hilia, kapecong dan iliran bukit, dekat rumah Tuan Tukua, pas sekali sebelum turunan itu, kalau diambil garis lurus dia akan bertemu dengan yang di Pecong, Buya Solok, dan ini anaknya, lalu diambil vertikal, maka akan menghasilkan garis lurus. Orang-orang yang ada di Pecong itu lebih rincinya karena inyiak/buyut beliau ini, ini kan anak Buya Solok, kalau sudah menggelegar itu, ada saja kemungkinan yang akan terjadi, kemungkinan yang pertama itu bisa saja Tarusan itu genang, kemungkinan keduanya itu ada musibah yang akan terjadi, menggelegarnya itu seperti bunyi gluduk/petir, tapi dia dari bawah tanah, dari bawah menggelegarnya, kalau gluduk/petir kan dari atas, bunyinya terdengar oleh orang, saya pernah mendengarnya, waktu saya tidur dengan bapak di simpang, seringkali saya mendengarnya, jadi Buya Solok ini adalah cucu dari orang-orang itu, orang orang ini bersaudara, jadi yang di Pecong dengan yang di Hilir orangnya/ mereka bersaudara, yang Buya Solok di simpang itu cucunya.

From the story, there is a connection between one grave and another because they have a bloodline relationship. Strange things that happen indicate that an event or disaster will occur in the surrounding community by the sound of booming voices from each grave. This actually shows the communal harmonization that occurs because the cemetery has a family relationship. And those people are the leaders of that society.

\section{Conclusion}

From this explanation, it can be concluded that the presence of folklore in society is not only a recounting of events in the past, as well as questioning whether or not the event occurred. The presence of folklore in society has a positive impact on the community in carrying out life activities between one another, because in the Kamang Mudiak folklore text it contains social functions such as: developing community integration, social control tools, strengthening social solidarity, group identity, harmonization communal for the surrounding community and become a marker for their respective areas. As well as being used as a confirmation of the local cultural heritage in Kamang Mudiak.

\section{Politeness}

The authors would like to thank all those who have supported so that this research can be carried out properly so that it reaches the writing of the article. Like the informants in the Kanagarian Kamang Mudiak, fellow lecturers, students, and LPPM Universitas Bung Hatta.

\section{REFERENCES}

Devianty, R. (20I7). Bahasa sebagai cermin kebudayaan. Jurnal tarbiyah, 24(2).

Ibrahim, R. (2015). Pendidikan Multikultural: Pengertian, Prinsip, dan Relevansinya denganTujuan Pendidikan Islam. Addin, $7(\mathrm{I})$.

Baharun, H., \&Awwaliyah, R. (2017). Pendidikan Multikultural dalam Menanggulangi Narasi Islamisme di Indonesia. Jurnal Pendidikan Agama Islam (Journal of Islamic Education Studies), 5(2), 224-243. 
Mania, S. (2010). Implementasi Pendidikan Multikultural dalam Pembelajaran. Lentera Pendidikan: Jurnal Ilmu Tarbiyah dan Keguruan, I3(I), 78-9I.

Awaru, A. O. T. (2017, February). Membangun Karakter Bangsa Melalui Pendidikan Berbasis Multikultural Di Sekolah. In Prosiding Seminar Nasional Himpunan Sarjana Ilmu-Ilmu Sosial(Vol. 2, pp. 22I-230).

Ambarudin, R. I. (2016). Pendidikan multikultural untuk membangun bangsa yang nasionalis religius. Jurnal Civics, I3 (I), 28-45.

Isnanda, R., \& Azkiya, H. (2019). PEMBERDAYAAN SANGGAR BUDAYA LOKAL DI KANAGARIAN KAMANG MUDIAK KECAMATAN KAMANGMAGEK KABUPATEN AGAM. Dharmakarya, 8(3), I63-I69.

Amin, I., \& Syahrul, R. (2013). Cerita Rakyat Penamaan Desa di Kerinci: Kategori dan Fungsi Sosial Teks. Bahasa, Sastra, dan Pembelajaran, $I(\mathrm{I})$.

Sutriati, N., Hasanuddin, W. S., \& Zulfadhli, Z. (2012). Kategori dan Fungsi Sosial Cerita Rakyat di Kenegerian Kari Kecamatan Kuantan Tengah Kabupaten Kuantan Singingi Provinsi Riau. Pendidikan Bahasa Indonesia, I(I), I26I3I.

Nurkhalis, N. (2019). Fungsi Sosial Pada Tradisi Pantang Melaut Masyarakat Pesisir Aceh. Community: Pengawas Dinamika Sosial, 4(2), I55-166.

Hijiriah, S. (2017). Kajian struktur, fungsi, dan nilai moral cerita rakyat sebagai bahan pembelajaran apresiasi sastra. Riksa Bahasa: Jurnal Bahasa, Sastra, dan Pembelajarannya, 3(I).

Dewita, S., \& Nasution, M. I. (2019). Struktur dan Fungsi Sosial Cerita Rakyat Batu Baimpik di Nagari Parambahan Solok. Jurnal Bahasa dan Sastra, 7(3), 258-266.

Isnanda, R. (2015). Struktur dan Nilai-Nilai Pendidikan dalam Cerita Rakyat Kabupaten Tanah Datar Provinsi Sumatera Barat. Jurnal gramatika, I(2), 79730.

Hasanuddin WS. 2003. Transformasi dan Produksi Sosial Teks Melalui Tanggapan dan Penciptaan Karya Sastra: Kajian Interstekstualitas Teks Cerita Anggun Nan Tongga Magek Jabang. Bandung: Dian Aksara Press.

Moleong, Lexy J. 20I0. Metode Penelitian Kualitatif. Bandung: Remaja Rosdakarya.

Asnawi, A. (2020). Kategori dan Fungsi Sosial Teks Cerita Rakyat Mayarakat Banjar Hulu: sebagai Pengukuh Warisan Kebudayaan Lokal Bangsa. Jurnal Sastra Indonesia, 9 (3).

Asnawi, A. (2020). Kategori dan Fungsi Sosial Teks Cerita Rakyat Mayarakat Banjar Hulu: sebagai Pengukuh Warisan Kebudayaan Lokal Bangsa. Jurnal Sastra Indonesia, 9(3), 2I2-22I.

Nur, M. (2019). Nilai-Nilai Pendidikan Agama Islam Dalam Konsep Pendidikan Multikultural. El-Buhuth: Borneo Journal of Islamic Studies, 2.

Wakano, A. (2019). Nilai-nilai Pendidikan Multikultural dalam Kearifan Lokal Masyarakat Maluku. al-Iltizam: Jurnal Pendidikan Agama Islam, 4(2), 26-43.

Wahab, A. (202I). Internalisasi Nilai-nilai Pendidikan Multikultural dalam Pembelajaran Fikih pada MTs DDI Kaballangang Kabupaten Pinrang. Al-Musannif, 3(I), I-I4.

Hamidy, UU. 2006. Jagad Melayu dalam Lintas Budaya di Riau. Pekanbaru: Bilik Kreatif Press. 